\title{
LOTUS PEDUNCULATUS ESTABLISHMENT IN INTENSIVE FARMING
}

\author{
J. L. Brocr and J. F. L. Charl.ton \\ Grasslands Division, DSIR, Palmerston North
}

\section{A bsiract}

Higher levels of lotus establishment were obtained in mixed pastures by broadcast sowing compared with drilling in early spring, using high seed rates (3 to $5 \mathrm{~kg} / \mathrm{ha}$ ) and no fertilizer, followed by lenient management (long spells and lax grazing) which may include conservation.

The establishment phase of lotus extends until adequate $\mathrm{N}$ fixation and taproot and rhizome development have occurred to increase persistency, which takes one or even two years from sowing.

While lotus has valuable properties for intensive farming, the agronomic characters of the present varieties fall far short of those required for its success in this situation. Farmers wishing to use lotus in mixed pastures must be prepared to adopt special management procedures to establish and maintain this legume.

\section{INTRODUCTION}

IN New Zealand the distribution of Lotus pedunculatus Cav. is in areas where soil fertility, grazing pressure and competition art low (Levy, 1970) . It was introduced largely as a replacement for white and red clovers which were failing after the initial fertility of the "bush burn" had declined, and as such was widely used up to the early 1900s (Levy, 1918 ). With the build up of pasture fertility under more intensive farming systems, lotus was unable to survive because of poor seedling vigour and regrow th following defoliation. Attempts to improve establishment led to the development by Grasslands Division of three diploid and two tetraploid selections. The larger seeded tetraploids displayed greater seedling vigour than the diploids, and one incorporntmg winter-active material from Portugal (Barclay and Lambert, 1970) is now commercially available as 'Grasslands Maku' (Armstrong, 1974). Experimental evidence to date has shown it to be of value for revegetation of eroded high country (Nordmeyer and Davis, 1976), and in the acid tussock grassland areas of Otago (Lowther, 1976). The diploid counterpart of Maku, 'Grasslands 4703', has a more prostrate habit and has exhibited greater persistency under harder grazing than Maku (Harris et al., 1973; Lambert et al., 1974). 
TABLE 1: EXPERIMENTAL DETAILS OF LOTUS EVALUATIONS UNDER HIGH SOIL FERTILITY CONDITIONS IN MANAWATU

\begin{tabular}{|c|c|c|c|c|}
\hline Location & $\begin{array}{l}\text { Site History* } \\
\text { Sowing D etails }\end{array}$ & Legumes & In Species Grasses & $M$ anagement \\
\hline $\begin{array}{l}\text { Levin }- \text { town milk } \\
\text { supply farm (area } \\
1.6 \text { ha) }\end{array}$ & $\begin{array}{l}\text { Maize feed crop } \\
\text { 1. Broadcast } \\
\text { 2. Drilled } \\
\text { 300 kg/ha super- } \\
\text { phosphate } \\
\text { March } 16,1976\end{array}$ & $\begin{array}{l}\text { I. Maku } 3 \mathrm{~kg} / \mathrm{ha} \\
\text { 2. G4703 } 3 \mathrm{~kg} / \mathrm{ha}\end{array}$ & $\begin{array}{l}\text { Ruanui and Ariki rye- } \\
\text { grasses, Apanui cocks- } \\
\text { foot }-5 \mathrm{~kg} / \mathrm{ha} \text { each }\end{array}$ & $\begin{array}{l}\text { Rotationally break-grazed, } \\
\text { May-Sep. with } 20 \mathrm{~kg} \mathrm{~N} / \\
\text { ha in July } \\
\text { Silage crop, Sep.-Nov. + } \\
20 \mathrm{~kg} \text { N/ha on half area. } \\
\text { Rotationally grazed Dec. on }\end{array}$ \\
\hline $\begin{array}{l}\text { Kopane }- \text { seasonal } \\
\text { milk supply farm } \\
\text { (area } 0.27 \text { ha) }\end{array}$ & $\begin{array}{l}\text { Maize and barley } 1 \\
\text { crops } \\
\text { Broadcast, no } \\
\text { fertilizer } \\
\text { April } \overline{23,1976}\end{array}$ & $\begin{array}{l}\text { 1. Maku } 5 \mathrm{~kg} / \mathrm{ha} \\
\text { 2. G4703 } 5 \mathrm{~kg} / \mathrm{ha}\end{array}$ & 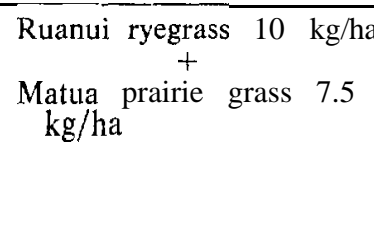 & $\begin{array}{l}\text { a Rotationally grazed Oct.- } \\
\text { Nov. } \\
\text { Hay crop Nov.-Dec. } \\
\text { Rotationally grazed Jan. on }\end{array}$ \\
\hline $\begin{array}{l}\text { Kairanga }- \text { experi- } \\
\text { mental sheep graz- } \\
\text { ing (area } 0.8 \text { ha) }\end{array}$ & $\begin{array}{l}\text { Cereal crop } \\
\begin{array}{l}\text { Broadcast, no } \\
\text { fertilizer }\end{array} \\
\text { May } 7 \overline{1975}\end{array}$ & $\begin{array}{l}\text { 1. Maku } 5 \mathrm{~kg} / \mathrm{ha} \\
\text { 2. Huia } 5 \mathrm{~kg} / \mathrm{ha} \\
\text { 3. Maku } 5 \mathrm{~kg} / \mathrm{ha} \\
++ \\
\text { Huia } 1 \mathrm{~kg} / \mathrm{ha}\end{array}$ & $\begin{array}{l}\text { Ruanui/Manawa rye- } \\
\text { grass }(3: 1) \text { at: } \\
\text { 1. } 7.5 \mathrm{~kg} / \mathrm{ha} \\
\text { 2. } 20 \mathrm{~kg} / \mathrm{ha}\end{array}$ & $\begin{array}{l}\text { Mob stocking }(500-800 \\
\text { sheep/ha) } \\
\text { 1. Frequent hard grazing } \\
\text { (3-4 weekly), lax grazing } \\
\text { 2. Infrequent, lat } \\
\text { (6-8 weekly) }\end{array}$ \\
\hline $\begin{array}{l}\text { Palmerston North } \dagger- \\
\text { experimental mow- } \\
\text { ing (small plots) }\end{array}$ & $\begin{array}{l}\text { Spaced plants } \\
\text { Broadcast in } \\
\text { 1. April, or } \\
\text { 2. September } 1976 \\
\text { with } \\
\text { 1. No fertilizer or } \\
\text { 2. } 200 \mathrm{~kg} / \text { ha super. }\end{array}$ & $\begin{array}{l}\text { 1. Maku } 3 \mathrm{~kg} / \mathrm{ha} \\
\text { 2. Huia } 3 \mathrm{~kg} / \mathrm{ha} \\
\text { 3. Maku } 3 \mathrm{~kg} / \mathrm{ha} \\
\text { Huia } 1 \mathrm{~kg} / \mathrm{ha}\end{array}$ & $\begin{array}{l}\text { Ruanui/Nui ryegrass } \\
\text { (1:1) at: } \\
\text { 1. } 7.5 \mathrm{~kg} / \mathrm{ha} \\
\text { 2. } 15 \mathrm{~kg} / \mathrm{ha} \\
\text { 3. } 22.5 \mathrm{~kg} / \mathrm{ha}\end{array}$ & $\begin{array}{l}\text { Cut by reel mower. } \\
\text { 1. Frequent }(10-4 \mathrm{~cm}) \\
\text { 2. Infrequent }(20-4 \mathrm{~cm})\end{array}$ \\
\hline
\end{tabular}

All sites originally from long-term permanent pastures, hence substantial buried white clover seed population. 
Recently interest has refocused on lotus as a possible mcans of reducing grass grub damage (Kain and Atkinson, 1975) as well as bloat (Jones et al., 1970), thus making it potentially valuable in more intensive farming situations usually considered unfavourable for persistence of this species. There has been little evaluation of techniques required for the successful establishment and management of Maku in such situations.

This paper reports results from several experiments on establishment of lotus in mixed pastures on high fertility soils in Manawatu.

\section{METHODS}

Details of evaluations are given in Table 1 .

In all cases lotus seed was inoculated with the appropriate Rhizobium strain immediately before sowing. The farm evaluations were unreplicated, and the sheep grazing evaluation had two replicates. The mowing evaluation, of which only the first replicate has been completed to date, will have two further replicates, one sown each year to allow for climatic variations.

Higher seeding rates ( 3 to $5 \mathrm{~kg} / \mathrm{ha}$ ) were used to ensure adequate numbers of seedlings, as lateral spread of lotus by rhizomes is slow (Lowther, 1976).

\section{RESULTS AND DISCUSSION}

\section{DaIRy Farm EVALUATIONS}

Normal dairy Farm pasture management was practised during the trials. This meant an early sowing and frequent grazing to maintain milk production on the town milk supply farm at Levin (Table 2), while at Kopane (Table 3). carrying only dry stock over winter, it was possible to sow later and defer grazing to mid-spring.

The comparison of drilling and broadcast sowing at Levin showed drilling to have an initial nodulation advantage but broadcasting gave greater seedling numbers and larger seedling size. This may have been due to drilling too deep, which Smetham (1973) indicated should not exceed 0.6 to $1.2 \mathrm{~cm}$.

At both sites Maku seedlings were larger than G4703, but the latter gave a higher seedling density-. The contrast in early management between the two sites had a great effect on lotus establishment by mid-spring. In Levin, frequent break-grazing and $\mathrm{N}$ application had almost eliminated lotus, whereas the absence of -grazing over winter at Kopane resulted in a 10\% lotus com- 
TABLE 2: GROWTH AND PERFORMANCE OF MAKU AND G4703 LOTUS AT LEVIN

\begin{tabular}{|c|c|c|c|c|c|c|}
\hline \multirow[b]{2}{*}{ Date } & \multirow[b]{2}{*}{ Parameter } & \multicolumn{2}{|c|}{$M a k u$} & \multicolumn{2}{|c|}{ G4703 } & \multirow{2}{*}{$\begin{array}{l}\text { White } \\
\text { Clover }\end{array}$} \\
\hline & & Broadcast & Drilled & Broadcast & Drilled & \\
\hline \multicolumn{7}{|l|}{1976} \\
\hline Mar. 16 & Seed sown $/ \mathrm{m}$ ' & 380 & 380 & 570 & 570 & \\
\hline \multirow[t]{2}{*}{ May 4} & Seedlings/n? & 250 & 75 & 530 & 50 & \\
\hline & $\begin{array}{c}\text { Shoot DW (mg) } \\
\% \text { Nodulation }\end{array}$ & $\begin{array}{l}5.9 \\
55\end{array}$ & $\begin{array}{l}4.1 \\
92\end{array}$ & $\begin{array}{c}4.0 \\
45\end{array}$ & $\begin{array}{r}2.3 \\
63\end{array}$ & \\
\hline Sep. 9 & $\%$ of total yield & trace & 0.3 & 1. 3 & trace & 0.6 \\
\hline \multirow[t]{3}{*}{ Nov. 9} & $\%$ of total yield & & & & & \\
\hline & $\mathrm{N}-$ & 11 & 7 & 18 & 3 & 5 \\
\hline & $\mathbf{N}+$ & 2 & 2 & 11 & 3 & 6 \\
\hline \multicolumn{7}{|l|}{1977} \\
\hline Apr. 15 & $\mathrm{~N}-$ & 6 & 3 & 18 & 5 & 23 \\
\hline Jul. 13 & $\mathrm{~N}-$ & 0 & 0 & 7 & 1 & 17 \\
\hline
\end{tabular}

TABLE 3: GROWTH AND PERFORMANCE OF MAKU, G4703 AND VOLUNTEER WHITE CLOVER AT KOPANE

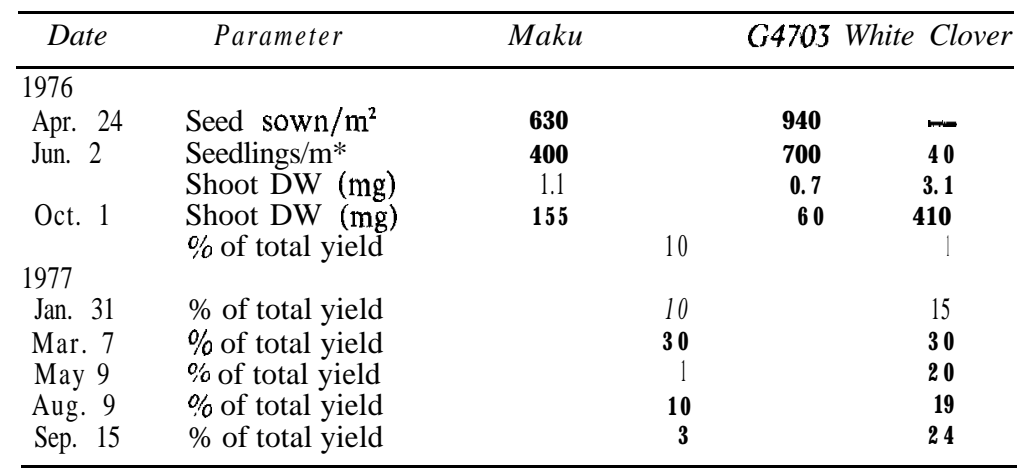

ponent in the pasture. Closing for a silage crop at Levin gave a partial recovery but lotus content never reached the level of the Kopane site for the rest of the year. Nitrogen applied to half the silage crop at Levin resulted in $\mathrm{GO} \%$ reduction in size of lotus plants and reduced lotus content, presumably through increased competition from companion grasses. With cooler weather in April, lotus growth rate rapidly decreased and made little growth above 3 to $5 \mathrm{~cm}$, thus contributing little to pasture yield. By late winter some recovery was evident at Kopane after a long spell (13 weeks), but following grazing recovery in early spring was poor. At Levin under more frequent grazing winter growth was poor. G4703 tended to be slightly better than Maku in summer, 
especially at Levin under frequent grazing, as had been Indicated by Lambert et al. (1974).

Apart from the cooling climate in April, another explanation for the rapid decline in lotus shoot growth is that during late summer-autumn up to $\mathbf{7 0 \%}$ of total growth can be diverted into taproot and rhizome development (Sheath, 1976), important for carbohydrate storage, and lateral spread which increases numbers of regrowth sites, and hence persistency.

Throughout the year volunteer white clover had been establishing from buried seed $(10 \mathrm{~kg} / \mathrm{ha}$ in the top $7.5 \mathrm{~cm}$ of soil after sowing at Levin). Seedling growth was three times as great as Maku at Kopane and by autumn had reached a level consistent with that from newly sown clover/grass pastures in this situation. This illustrates the competitive problem facing lotus from this species during establishment.

\section{EVAluation under Shemp Grazing}

During the first year, grazing criteria (Table 1) were carefully controlled to apply to the legumes, but in the second year were applied to the whole pasture to eliminate the large amount of topping required. The results presented in Fig. 1 apply to the second year only.

By the end of the first year, best lotus establishment $(28 \%$ of total yield) had resulted from infrequent grazing and high

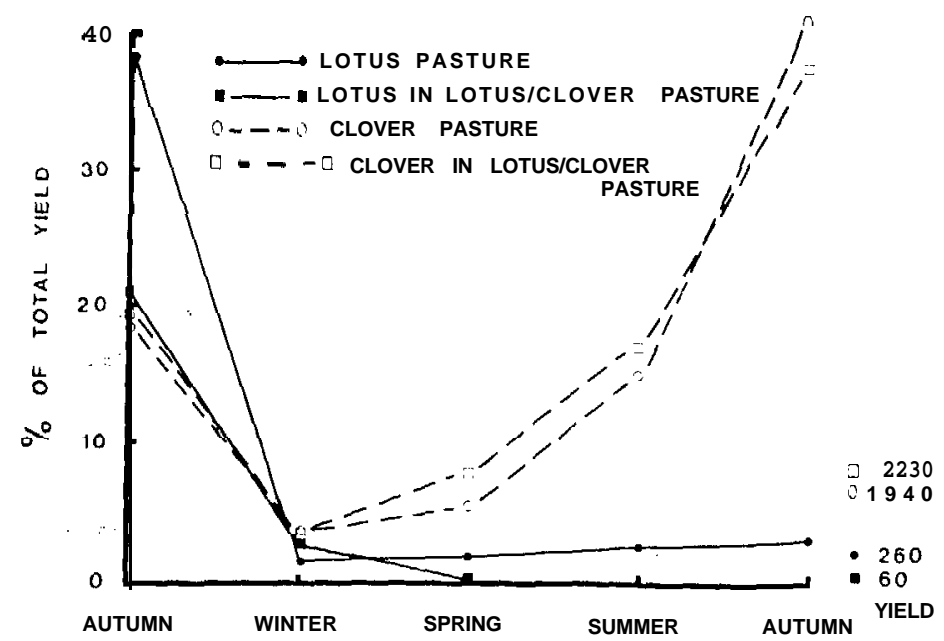

FIg. 1: Contribution to total. yield of Maku lotus and white clover in the laxly grazed, high grass seed rate treatment under sheep. 
grass seeding rate, with ingress of white clover (sown or volunteer) being particularly high under. the frequently grazed low grass seed rate treatment. In the second year, lotus was virtually eliminated and was replaced by white clover. Resting for a hay crop in summer had little effect. Smetham (1973) suggested that selective grazing would be a major problem for lotus under low stocking rates, and may be reduced at higher stocking rates. However, the high stocking rates used in this trial apparently did not reduce selectivity. Rhizome production should have developed before grazing pressure was increased, thereby aiding persistency, but as new rhizomes only develop adventitious roots which are restricted by low moisture levels (Sheath, 1976), they may have failed to produce adequate anchoring roots and been stripped off during grazing. Possibly two years of lenient treatment as in year 1 are required to develop the required persistency to withstand heavier grazing.

\section{MOWING EVALUATION}

Grass seeding rate had little effect on any treatment. Autumnsown lotus was generally poor in all treatments despite relatively good initial establishment. The vigorous ryegrass (and white clover where sown) rapidly dominated by October (Fig. 2). Cutting frequency and $\mathrm{P}$ application had no effect.

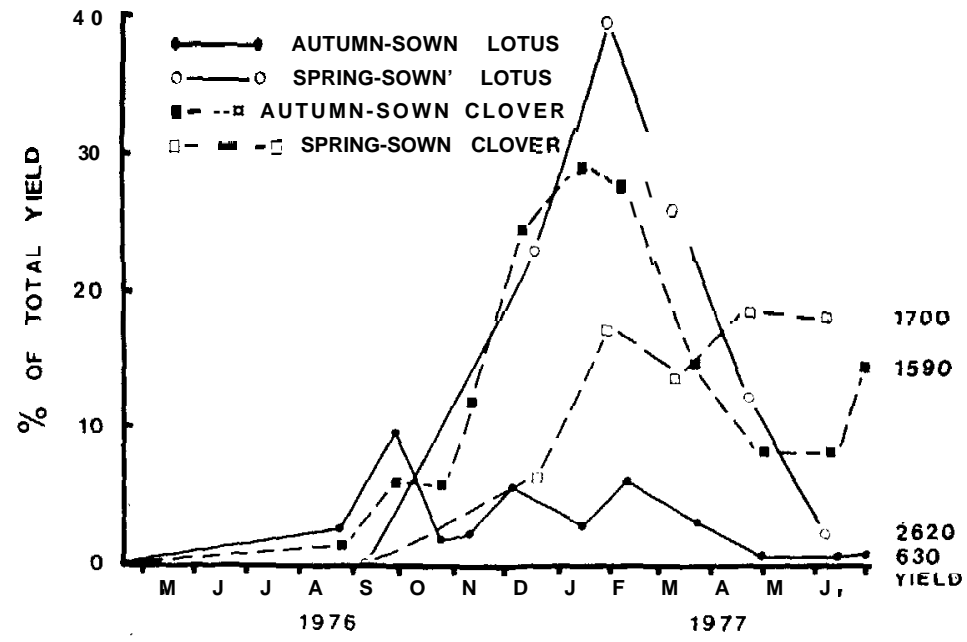

Frg. 2: Rate at which whife clover dominafed Maku lotus from autumn and spring sowings. 
TABLE 4: EFFECT OF CUTTING FREQUENCY AND SEASON OF SOWING ON ANNUAL LOTUS YIELD (kg DM/ha) UNDER MOWING

\begin{tabular}{lllcc}
\hline Cuffing & & & \multicolumn{2}{c}{ Sowing Date } \\
Frequency & & & Aufumn & Spring \\
\hline Frequent & $\ldots$ & $\ldots$ & $615 \mathrm{c}^{*}$ & $1880 \mathrm{~b}$ \\
Infrequent & $\ldots$ & $\ldots$ & $765 \mathrm{c}$ & $3050 \mathrm{a}$ \\
\hline
\end{tabular}

*Duncan's Multiple Range Test - means without common letter differ significantly at $\mathbf{P}<\mathbf{0 . 0 5}$.

TABLE 5: EFFECT OF SUPERPHOSPHATE ON LOTUS/WHITE CLOVER BALANCE (kgDM/ha) FROM SPRING AND AUTUMN SOWING

\begin{tabular}{lccccc}
\hline Sowing & $\begin{array}{c}\text { Superphosphate } \\
(\mathrm{kg} / \mathrm{ha})\end{array}$ & Lotus & \multicolumn{2}{c}{$\begin{array}{c}\text { Legume Base } \\
\text { (Lotus + Clover) }\end{array}$} & Clo ver \\
\hline Autumn & 0 & $840 \mathrm{ef}$ & $910 \mathrm{ef}$ & $2370 \mathrm{~cd}$ & $2600 \mathrm{c}$ \\
& 200 & $650 \mathrm{f}$ & $680 \mathrm{f}$ & $2170 \mathrm{~cd}$ & $3400 \mathrm{~b}$ \\
Spring & 0 & $1980 \mathrm{~cd}$ & $2730 \mathrm{~b}$ & $1860 \mathrm{~cd}$ & $3380 \mathrm{~b}$ \\
& 200 & $1920 \mathrm{~cd}$ & $1530 \mathrm{de}$ & $2710 \mathrm{~b}$ & $5280 \mathrm{a}$ \\
\hline
\end{tabular}

In contrast, spring-sown ryegrass was much less competitive and lotus established satisfactorily. Infrequent cutting $(20$ to $4 \mathrm{~cm})$ greatly increased lotus yield (Table 4) and not until the following April did white clover dominate the lotus (Fig. 2) as in the farm evaluations. From Table 5 it is evident that, in the absence of superphosphate, lotus benefited from its association with white clover, possibly through better $\mathrm{N}$ nutrition, as Brock (1973) indicated that an effective $\mathrm{N}$ fixation system in lotus may take more than a year to develop. Superphosphate applied at spring sowing increased white clover growth to the detriment of lotus, while autumn application at sowing benefited white clover only in the absence of lotus. These results are the reverse of those of Lowther (1976) on acid tussock grasslands in Otago.

Following the cool April conditions, lotus did not grow above cutting height and had this experiment been under sheep grazing it is doubtful whether the lotus would now survive sclective grazing over the winter.

\section{CONCLUSIONS}

From these results, the requirements for successful lotus establishment in mixed pastures on high fertility would appear to be: 
(1) High seeding rate to ensure high seedling derısity,

(2) No fertilizer at sowing.

(3) Minimal competition from white clover.

(4) No sheep grazing.

(5) Lenient and infrequent grazings..

\section{Alternative Estabishment Methods}

Two alternative methods have been examined by the Soil and Field Research Division of MAF at Takapau in southern Hawke's Bay (W. M. Kain and I. M. Ritchie, pers. comm.) . One method involves direct drilling of alternate rows of lotus and white clover separated by a ryegrass row, to reduce the spread of white clover. A second approach aims to establish lotus as pure stands under a cereal cover crop, overdrilling the grasses in the following autumn.

Another possibility being tried in commercial practice is taking a lotus seed crop in the first year, although control of weeds by use of herbicides might be required to ensure success. In these circumstances volunteer white clover could be suppressd by application of ethofumesate (Brock and Henderson, 1976). Seed production may even be required for two years, the extra time allowing greater build-up of rhizomes and taproots, thereby resulting in greater persistency.

\section{ThE INFORMATION GAP}

Despite the desirable attributes of grass grub and bloat control, the results of these trials indicate that, compared with white clover, lotus is unsatisfactory in yield, growth and rate of recovery from defoliation under intensive management. It would appear that, without a costly regular herbicide spraying programme and specialized management, pure lotus-based pastures will be difficult to establish and maintain under commercial practice, as white clover volunteering from buried seed will always be a problem. Animal productivity studies showed that sheep liveweight gains were 23\% higher from white clover than lotus, which was similar to red clover (Ulyatt, et al., 1976). In terms of pasture quality, then, it may be desirable to have both lotus and white clover in the pasture if possible. In this case information on the proportion of lotus required in the pasture to give adequate control of grass grub and bloat is needed. It has been suggested that a $20 \%$ content of lotus in herbage 
may be enough to maintain grass grub control (Kain and Atkinson, 1977; East and King, 1977), but as yet the equivalent information for bloat control is not available.

In summary, present lotus material has valuable properties for intensive farming, but its agronomic characteristics fall far short of those required for its success in this situation. Recent studies on Maku have more closely defined its regrowth characteristics, indicating it to be better suited to conservation type systems, not intensive grazing (G. W. Sheath, pers. comm.). Perhaps, with such information forthcoming, we are now in a position to re-assess the role of the present lotus varieties, to form new objectives, then proceed with the necessary development of suitable types.

\section{ACKN OWLEDGEMENTS}

M. Rolston of Levin, and K. Odgers of Kopane, on whose properties evaluations were conducted. J. D. Henderson for assistance in the field, and the staff of the Herbage Dissection Laboratory, Grasslands Division, DSIR, Palmerston North.

\section{REFERENCES}

Armstrong, C. S., 1974. N.Z. $/ l$ exp. A gric., 2: 333-6.

Barclay, P. C.; Lambert, J. P., 1970. Proc. 1 1th int. Grassld Congr.: 278-81. Brock, J. L., 1973. N.Z. Il A gric., 16: 483-91.

Brock, J. L.; Henderson, J. D., 1976. Proc. N.Z. Weed \& Pest Control Cont., 29: 93-6.

East, R.; King, P. D., 1977. N.Z. Entomologist, 6: in press.

Harris, A. J.; Brown, K. J.; Turner, J. D.; Johnston, J. M.; Ryan, D. L.; Hickey, M. J., 1973. N.Z. $/ 1$ exp. Agric., I: 139-63.

Jones, W. T.; Lyttleton, J. W.; Clarke, R. T. J., 1970. N.Z. /l agric. Res., 13: 149-56.

Kain, W. M.; Atkinson, D. J., 1975. proc. N.Z. Grassld A ss., 37: 132-7. 1977: N.Z. Jl agric. Res., 20: in press.

Lambert, J. P.; Boyd, A. F.; Brock, J. L., 1974. N.Z. $/ l$ exp. Agric., 2: 359-63.

Levy, E. B., 1918. N.Z. Jl A gric., 17: 347-51.

ton.

1970. Grasslands of New Zealand. Government Printer, Welling-

Lowther, W. L., 1976. Proc. N.Z. Grassld A ss., 38: 133-9

Nordmever. A. H.: Davis. M. R., 1976. Ibid., 38: 119-25.

Sheath, G. W., 1976. Ibid., 38: 215-20.

Smctham, M. L., 1973. In Pasfures and Pasture Plants (Ed. R. H. M. Langer) : 85-128. Reed, Wellington.

Ulyatt, M. J.; Lancashire, J. A.; Jones, W. T., 1976. Proc. N.Z. Grassld A SS., 38: $107-18$. 